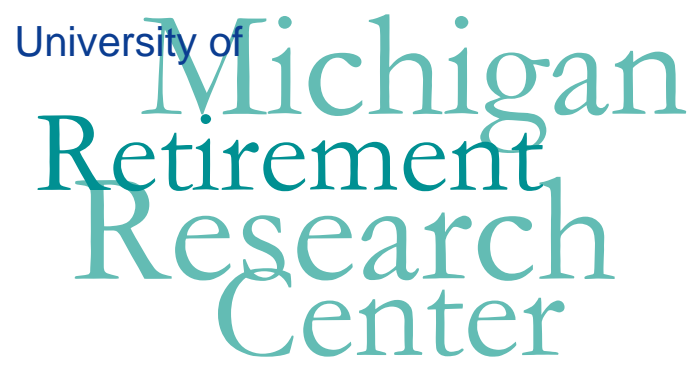

Working Paper

WP 2008-192

\title{
Labor Market and Immigration Behavior of Middle-Aged and Elderly Mexicans
}

Emma Aguila and Julie Zissimopoulos

\begin{tabular}{|l|l|l|}
\hline $\mathrm{M}$ & $\mathrm{R}$ \\
\hline $\mathrm{R}$ & $\mathrm{C}$ & \\
\hline
\end{tabular}$\quad$ Project \#: UM08-14 


\title{
Labor Market and Immigration Behavior of Middle-Aged and Elderly Mexicans
}

\author{
Emma Aguila \\ RAND \\ Julie Zissimopoulos \\ RAND
}

September 2008

\author{
Michigan Retirement Research Center \\ University of Michigan \\ P.O. Box 1248 \\ Ann Arbor, MI 48104 \\ http://www.mrrc.isr.umich.edu/
}

(734) 615-0422

\section{Acknowledgements}

This work was supported by a grant from the Social Security Administration through the Michigan Retirement Research Center (Grant \# 10-P-98362-5-04). The findings and conclusions expressed are solely those of the author and do not represent the views of the Social Security Administration, any agency of the Federal government, or the Michigan Retirement Research Center.

\section{Regents of the University of Michigan}

Julia Donovan Darrow, Ann Arbor; Laurence B. Deitch, Bingham Farms; Olivia P. Maynard, Goodrich; Rebecca McGowan, Ann Arbor; Andrea Fischer Newman, Ann Arbor; Andrew C. Richner, Grosse Pointe Park; S. Martin Taylor, Gross Pointe Farms; Katherine E. White, Ann Arbor; Mary Sue Coleman, ex officio 


\title{
Labor Market and Immigration Behavior of Middle-Aged and Elderly Mexicans
}

\author{
Emma Aguila and Julie Zissimopoulos
}

\begin{abstract}
In this study we analyzed the retirement behavior of Mexicans with migration spells to the United States that returned to Mexico and non-migrants. Our analysis is based on rich panel data from the Mexican Health and Aging Study (MHAS). Approximately 9 percent of MHAS respondents aged 50 and older reported having lived or worked in the United States. These return migrants were more likely to be working at older ages than non-migrants. Consistent with much of the prior research on retirement in the United States and other developed countries, Mexican non-migrants and return migrants were responsive to institutional incentives. Both groups were more likely to retire if they had publicly provided health insurance and pensions. In addition, receipt of U.S. Social Security benefits increased retirement rates among return migrants. Return migrants were more likely to report being in poor health and this also increased the likelihood of retiring. The 2004 draft of an Agreement on Social Security would coordinate benefits across United States and Mexico boundaries to protect the benefits of persons who have worked in foreign countries. The agreement would likely increase the number of authorized and unauthorized Mexican workers and family member eligible for Social Security benefits. The responsiveness of current, older Mexican return migrants to pension benefits, suggests that an Agreement would affect the retirement behavior of Mexican migrants.
\end{abstract}

\section{Authors’ Acknowledgements}

We thank Joanna Carroll for her excellent programming assistance and Claudia Diaz for her excellent research assistance. 


\section{INTRODUCTION}

Many Mexicans near retirement age will have spent part of their working lives in the United States and this will impact their lifetime earnings, accumulation of retirement wealth and decision of when to retire. Indeed, one in six men 50 years or older and residing in Mexico are former U.S. migrants (Wong, Soldo and Palloni, 2003). There is no doubt in the literature that Mexican migrants move to the United States due to the wage differentials with Mexico. Although work years in the United States may result in lifetime earnings that are higher than they otherwise would have been, a history of migration may also impact eligibility for retirement pension benefits and amount of benefit. In both the United States of America and Mexico, public retirement benefits are based on minimum years of work requirement and the amount of benefit is based on earnings. Despite the importance of migration in the work lives of many Mexicans, the effect of the migration experience on the retirement decisions of older Mexicans is not well understood.

The importance of portability of years of work from one country to another in order to qualify for Social Security retirement benefits has long been recognized by the United States. Most agreements are with European countries, in the American continent with Canada and Chile, in Asia with South Korea, and in the Pacific Oceania with Australia. These agreements make portable between countries years of contribution to the social security system and eliminate dual social security taxation for employees sent by a firm to another country and required to pay social security contributions in both countries. Mexico has social security agreements with Argentina, Canada, Italy, and Spain.

In June 2004, an agreement between the United States and Mexico coordinating social security benefits was drafted but has yet to be approved. The Agreement on Social Security between the United States and Mexico aims to coordinate pension benefits to eliminate dual taxation and fill benefit gaps. The agreement would permit claiming social security benefits according to the proportional part individuals contribute to each system (Martínez, 2007; Agreement on Social Security between the Unites States of America and the United Mexican States, 2004). To shed light on the labor force behavior and retirement decisions of older Mexicans with and without a history of migration to the United States, and considering how a Totalization Agreement between the U.S. and Mexico may affect retirement of Mexicans, this paper describes the following analyses. 
First, using the Mexican Health and Aging Study (MHAS), a rich, two wave panel survey of respondents in Mexico over age 50, we describe health care insurance in Mexico, social security systems' requirements, benefits and their retirement incentives. Second, we discuss our empirical methods including the concepts and variables used to capture labor status, migration histories, income and wealth, pensions and health insurance, health indicators as well as socioeconomic characteristics and our multivariate model of retirement. Third, we present results on the characteristics, migration history, health care insurance, social security benefits, labor status and labor force transitions of middle-age and older Mexicans with and without migration spells to the United States and our estimates from a multivariate retirement probability model.

We find that immigration is most likely to occur during prime working years and age of return to Mexico spikes around retirement age for long-term migrants. Compared to non-migrants, return migrants are more likely to be working at older ages. Compared to short-term migrants, long-term migrants, those that stayed more than a year in the United States, are more likely to have access to U.S. social security benefits, less likely to have Mexican Social Security benefits and public health insurance coverage. Based on multivariate models of retirement by migration status, we find that Mexican non-migrants and return migrants are responsive to institutional incentives but more so for return migrants. That is, while both groups are more likely to retire if they have health insurance and pensions, the effect is much larger for migrants. In addition, receipt of U.S. Social Security benefits increases retirement rates among return migrants. Return migrants are more likely to report being in poor health than non-migrants and this also increases the likelihood of retiring.

This paper is one of the first studies to analyze retirement behavior of Mexican return migrants. We contribute to the public policy debate exploring the characteristics of return migrants and the impact of social security rules on their retirement pattern. Because pension benefits in the U.S. and in Mexico is an important determinant of retirement, this analysis suggests that a Social Security Agreement between the United States and Mexico would likely have important implications for the retirement behavior of beneficiaries of the agreement. 


\section{BACKGROUND}

Previous literature has found that social security rules are an important determinant for retirement decisions around the world (for example see Gruber and Wise, 2004). Migrants that work outside their home country face additional incentives for retirement depending on the social security systems of the countries where they have a labor history. Compared to non-migrants, migrants have a higher risk of not meeting the minimum eligibility for social security benefits or not achieving full benefits in their home or host country, because most systems require contributions for the majority of prime working years to benefit in full from the plans. Due to the very high labor mobility between developed countries and from developing to developed countries the issues surrounding portability of benefits has become an increasingly important topic. To respond to this issue many countries have instituted Social Security agreements, also referred to as Totalization agreements, to make portable social security contributions between countries. The United States has a long history since 1973 of Social Security agreements with other countries (Butcher and Erdos, 1988). ${ }^{1}$ Mexico has agreements of this kind with other countries since $1977 .^{2}$

The Agreement on Social Security between the United States and Mexico. One of the most important migration flows in the world is between the United States and Mexico. In June 2004, an agreement between the United States and Mexico coordinating social security benefits was drafted. This agreement has not been approved and is not in effect. The Agreement on Social Security between the United States and Mexico aims to coordinate pension benefits to eliminate dual taxation and fill benefit gaps. The agreement would allow for summing the years of contribution in the U.S. and the Mexican system in order to meet the minimum eligibility requirements for social security benefits in each country. Upon satisfying the requirements to qualify for benefits in each country, social security benefits are computed in the U.S. and Mexico according to the proportional part of actual number of years of contribution in each country. Benefits

\footnotetext{
${ }^{1}$ The United States has this type of agreements with Italy (1978), Germany (1979), Switzerland (1980), Belgium (1984), Norway (1984), Canada (1984), United Kingdom (1985), Sweden (1987), Spain (1988), France (1988), Portugal (1989), Netherlands (1990), Austria (1991), Finland (1992), Ireland (1993), Luxemburg (1993), Greece, (1994), South Korea (2001), Chile (2001), Australia (2002), and Japan (2005).

${ }^{2}$ Mexico signed his first agreement with Italy (1977). Other agreements are with Argentina (1990), Spain (1994), and Canada (1995).
} 
correspond to the proportional part individuals contribute to each system (Martínez, 2007; Agreement on Social Security between the Unites States of America and the United Mexican States, 2004).

How a Totalization agreement between the United States and Mexico would affect the retirement behavior of Mexicans is unknown. With no Social Security Agreement, Mexicans with long spells of migration to the United States that return to Mexico (return migrants), are less likely than non-migrants to be eligible for social security benefits or health care insurance either in Mexico or the United States and thus may have additional incentives to work at older ages. On the other hand, return migrants may have different saving and wealth accumulation patterns that compensate for the loss of health and social security benefits. Return migrants with only a short migration spell to the United States may have similar retirement patterns as non-migrants given similar social security and health insurance benefits. Migrants, however, are not a random sample of the Mexican population. For example, Orrenius (1999) finds that return migrants are less educated than non-migrants.

Whether return migrants (and non-migrants) are entitled to social security benefits and health insurance in Mexico is also related to their work in the formal or informal sector before migration and upon return to Mexico. Individuals in the informal sector do not pay taxes or social security contributions. The informal sector represents an important proportion of the labor force. According to the OECD (2005), the informal sector is $25 \%$ of the labor force in Mexico. The formal sector includes private and public workers.

Health Care Insurance. Health care provision in Mexico is organized according to employment in the formal or informal sector. For those employed by the government and private sector, healthcare is granted by the social security system, which covers nearly half of the population. For the rest of the population, including self-employed and workers of the informal sector, healthcare services are provided by the Secretary of Health (SSA), the program IMSS-Oportunidades (previously known as IMSSSolidaridad) and Seguro Popular. Private health care services play an important role, mainly among non-insured families (OPS, 2002).

Social Security. In Mexico, social security is mainly provided by the Mexican Social Security Institute (IMSS), mandatory for private sector workers, and the Institute of Social and Security Services for Government Workers (ISSSTE) for public sector 
workers. ${ }^{3}$ IMSS reformed its pension system from a traditional pay-as-you-go (PAYG) to fully funded personal retirement accounts (PRA) in July 1997. ISSSTE reformed its pension system from a traditional PAYG to a PRA in September 2007. In 2000, IMSS covered 39.6 percent of the labor force and ISSSTE covered 5.7 percent of the labor force. Other social security institutions covering workers include Petróleos Mexicanos (PEMEX), a state-owned oil extraction and processing company, which provides its own healthcare services, and Instituto Social para las Fuerzas Armadas (ISSFAM) or Social Institute for the Armed forces, attending the armed forces, and universities, state and municipalities schemes.

Eligibility Requirements and Benefits. Individuals contributing to the pension system of IMSS or ISSSTE before the pension reform are the transition generation. The transition generation has the option to choose at retirement the highest pension according to the rules of the PAYG or the PRA as long as they satisfy the minimum requirements in each case. Those individuals that enter the systems after the reform are the new generation and they only have the option to retire according to the PRA rules. The PRA system requires at least 1,250 weeks of contribution or approximately 25 years. Under the PRA system retirement is possible at 65 years old and early retirement at age 60 is available for those that can obtain a pension equivalent to $130 \%$ of the minimum wage, which is the minimum pension guarantee.

The traditional PAYG of IMSS and ISSSTE were very similar. The early and normal retirement ages are 60 and 65 respectively for both men and women. The early retirement benefit is $15 \%$ less than that of the normal retirement pension. There is a minimum pension guarantee based on the minimum wage of Mexico City. The minimum years of contribution are 10 in both cases (500 weeks). IMSS and ISSSTE PAYG system is a final salary defined benefit. For IMSS, pensions are computed based on the average wage of the previous five years to retirement and for ISSSTE, the pension is computed based on the previous year to retirement. ISSSTE's PAYG replacement rate is higher than for IMSS (Aguila, 2008).

Retirement Incentives. If 15 percent is actuarially fair there are no incentives to delay retirement. The social security system has no penalties for continued working after normal retirement age and dependent benefits are given to the pensioner independent of

\footnotetext{
${ }^{3}$ For self-employed is not mandatory to contribute to the social security system.
} 
the working status of the spouse. Finally, the coverage of private, employer-provided pensions is very low. Less than $10 \%$ of firms in Mexico provide this benefit and in $61 \%$ of these plans normal retirement age is 65. In sum, pensions in Mexico provide few incentives for retiring at ages less than 65 (Aguila, 2006).

The determinants of retirement are well studied in the U.S. (examples of reviews are Hurd, 1990 and Lumsdaine and Mitchell, 1999) but are far less studied in Mexico. Aguila (2006), using MHAS data and forward looking measures of pension benefits finds that social security retirement benefits are an important predictor of retirement decisions, but does not examine how migration history impacts Social Security benefits or the decision of when to retire. Miranda-Muñoz (2004) finds that 19.5 percent of individuals that claimed a pension re-entered the labor market using the data from the Mexican National Survey of Aging Sociodemography 1994 (ENSE). In terms of the most important sources of income during retirement, Wong and Espinoza (2003) using the MHAS find individuals rely on pensions, family transfers and labor income.

This is the first study to exploit a rich panel data set, the MHAS, in order to understand the labor market behavior of middle-aged and older Mexicans by their migration history and how migration to the United States is associated with the decision of when to retire. We analyze the retirement behavior of Mexican return migrants and non-migrants taking into account Mexican social security benefits, health cares access, socioeconomic characteristics, health, labor earnings, household wealth and in addition, for return migrants, U.S. Social Security benefits, residency/citizenship in the United States, and length of migration spells to the United States.

\section{METHODS}

The MHAS is a two wave panel (years 2001 and 2003), that emphasizes retirement behavior and how it is affected by health status, economic status, and work incentives and is a nationally representative study of individuals born before 1951 and their spouses $(9,862$ households). The design of the MHAS questionnaire was based on the Health and Retirement Study (HRS), so the phrasing of questions is the same and the information is comparable (Soldo et al., 2002). MHAS has rich data particularly wellsuited for examining labor force behavior with detailed information on current work status and hours of work. The MHAS also contains information on demographic and 
employment characteristics, health, health care services provision, family transfers, detailed income and its sources, and wealth and its sources.

Moreover, the survey has information on immigration experiences to the United States including total number of years in the U.S., dates and duration for the first and last migration spell, networks in the U.S. that facilitate migration, and urban/rural location in the United States. The MHAS over-samples regions in Mexico with the highest quantity of migrants to the United States (Durango, Guanajuato, Jalisco, Michoacán, Nayarit and Zacatecas). We discuss our measurement of the key variables of interest in this analysis and describe our estimation methods in the remaining paragraphs of this section.

Labor Force Status. We classify individuals into three categories according to their current working status as full-time workers, part-time worker, or retired (not working). Full-time is defined as working more than 1,500 hours per year, and part-time is between 500 and 1,500 hours per year. The retirement category includes persons working less than 500 hours per year or reporting that they do not work.

Migration. MHAS respondents are asked in they have worked or lived in the United States excluding holidays or short visits. We classify individuals by their migration spells to the U.S. in three categories: non-migrants, short-term migrants and long-term migrants. Short-term migrants are those that have worked or lived in the U.S. up to a year. Long-term migrants are those persons that have worked or lived in the U.S. more than a year. We also develop an indicator variable of U.S. citizenship status including both permanent residency and citizenship. MHAS provides a broader perspective of migration histories than other surveys because we can analyze return migrants at ages 50 and older, after they have completed most of their working life.

Income and Wealth. Similar to the HRS, MHAS has detailed information on sources and amount of income and wealth and non-response is minimized due to the use of unfolding brackets. Our analysis utilizes total household income and net worth with imputed values from unfolding brackets for non-responses. Wong and Espinoza (2004) provide a detailed description of the imputation method. Total household income includes earned income, business profits, property rent income and expenses, capital assets income, income from pensions, family transfers, and transfers from government programs or individuals that are not family members. Net worth includes net of debt, the value of real estate properties, value of business and capital assets and vehicles, as well as 
other assets such as the value of savings and checking accounts. Income and net worth variables are deflated to pesos of 2002 as the base year with the Mexican official National Consumer's Price Index (NCPI) reported by the Mexican Central Bank (BANXICO) to be able to compare the 2001 and 2003 information.

Pensions and Health Insurance. We can identify the social security system to which the individual contributes: IMSS, ISSSTE, PEMEX, and ISSFAM. These social security institutes provide health care services and a pension system. The MHAS allows additionally identifying whether the individual has private health insurance. These data unfortunately does not allow for identifying if the individual contributes to an employerprovided, private pension or the U.S. social security system. However, we can observe when the individual receives social security benefits from the U.S. Social Security system or a private pension (or a Mexican institution). Workers contributing to IMSS are the transition generation although, with at most four years of contributions to the PRA, the eligibility rules of PAYG are most relevant. Workers contributing to ISSSTE are in the PAYG plan because the reform from PAYG to PRA was instituted in 2007.

Health indicators. Our analysis utilizes several measures of health. Self-reported health status is based on five categories: excellent, very good, good, fair, and poor. As another indicator of health, we utilize responses to the following questions: "Before age 10, did you have a serious health problem that affected your normal activities for a month or more?"

Education and Demographic characteristics. The education variable categorizes individuals by highest level of schooling completed: no schooling, incomplete primary, complete primary, incomplete high school, complete high school, and undergraduate studies or more. Other characteristics of interest include gender, age, marital status, number of children, and whether the individual speaks an indigenous dialect as an indicator of childhood poverty.

Multivariate model of transitions to retirement by migration status. We estimate a retirement conditional probability model:

$$
P\left(R_{i t}^{j}=1\right)=f\left(\alpha_{0}+\alpha_{1} X_{i t-1}^{j}+\alpha_{2} I_{i t-1}^{j}+\alpha_{3} H_{i t-1}^{j}+\alpha_{4} M_{i t-1}\right)
$$

Where $R_{i t}^{j}$ takes on the value 1 for individuals not working in 2003, conditional on working in 2001. That is, the sample includes only individuals who are working in 2001. $X_{i t}^{j}$ is a vector consisting of characteristics including age, education, number of children, 
marital status, and whether the individual speaks an indigenous dialect. $I_{i t}^{j}$ a vector of indicators for contribution to a social security institute, type of institute and if age-eligible for retirement benefits, and also includes indicators for health insurance type, household net worth, and household income. $H_{i t}^{j}$ is self-reported health status and childhood health, and $M_{i t}^{j}$ includes the age when the individual first immigrated to the United States, whether a short-term or long-term migrant, and whether a U.S. citizen or permanent resident. We estimate a Probit model separately for return migrants and non-migrants $(j=1,2)$ and separately for males and females.

\section{RESULTS}

This section presents the characteristics of the MHAS sample of middle-aged and elderly Mexicans. We analyze the demographic and socio-economic characteristics of respondents separately by whether they are non-migrants or return migrants (short-term or long-term). In addition, we study their health care and social security coverage, labor force status and labor transitions between 2001 and 2003. Finally, we present the estimation results of retirement probability models for male return migrants and male and female non-migrants and discuss the main factors that determine retirement for these groups. 4

In Table 1, we present the characteristics of 13,550 respondents from the 2001 MHAS. ${ }^{5}$ The mean age is 63 years and 53.9 percent are female. Over sixty percent have no schooling or incomplete primary, demonstrating the extremely low level of education of these cohorts in Mexico. The highest proportion of respondents has between 3 and 5 children (32.2 percent). The majority (60.7 percent) is married and lives in localities of more than a 100,000 inhabitants $(58.8$ percent). We find that 6.8 percent of the sample speaks an indigenous dialect. One of the poorest and least-educated groups is the indigenous population (Walton and Lopez-Acevedo, 2005). Of the 13,550 respondents 8.9 percent report that they have lived or worked in the United States.

\subsection{Migration Histories of Return Migrants}

\footnotetext{
${ }^{4}$ The sample size for female return migrants is too small to examine separately.

${ }^{5}$ We dropped those individuals below 50 years old in 2001 . We dropped 138 observations because they refused to respond or did not know whether they have lived in the United States.
} 
The 2001 MHAS has 1,212 Mexicans with migration history to the United States and 12,338 persons without migration experience in the United States. Of the migrants, 58.1 percent are long-term return migrants, to whom immigration to the U.S. lasted more than a year, and 41.9 percent are short-term return migrants that stayed in the U.S. up to a year. In Table 2 we present some of the characteristics of short-term return migrants, long-term return migrants, and non-migrants.

Education and Demographic Characteristics. Most return migrants are males. Approximately 85 percent of short-term return migrants and 78 percent of long-term return migrants are male. We find marked differences between short-term, long-term migrants, and non-migrants. Long-term migrants are more likely than short-term migrants to be female. This finding is consistent with some studies that find one of the important reasons for females to migrate is due to family reunification (for example UNDP, 2007; Binational Study on Migration, 1997). Overall, return migrants are less educated than non-migrants. A higher proportion of short-term migrants (69.2 percent) have no schooling or incomplete primary than long migrants (61.6 percent) or non-migrants $(59.8$ percent). A higher proportion of long-term migrants and non-migrants completed high school or undergraduate studies or more (16.8 and 17.0 percent respectively) compared with short-term migrants (12.0 percent).

Short-term migrants are more likely to have six or more children than long-term migrants and non-migrants (59.7, 55.0 and 49.7 percent respectively) and are more likely to be married than the other two groups. Although the majority of respondents live in localities of 100,000 inhabitants or more, short-term migrants are more likely to be from rural areas than long-term migrants and non-migrants.

Migration Experience. The experience in the U.S. was different for short and long term return migrants. Networks in the U.S. are important for migrants, particularly long-term migrants. Just over 38 percent of short-term migrants knew somebody in the U.S. to help them settle while almost 62 percent of long-term migrants had U.S. networks. Short-term migrants were more likely to live in rural areas of the U.S. than long-term migrants (55 versus 41 percent respectively). In the case of long-term migrants $21.1 \%$ are U.S. citizens or permanent residents, while only 5.5 percent of short-term migrants have this legal status. There are, however, several similarities between the migration experiences of short and long-term migrants. The median age of first 
migration to the United States is 26 for short-term and 25 for long-term migrants. Most migrate during prime working ages and only a small proportion of short-term (8.0 percent) and long-term (3.6 percent) migrants move to the U.S. for the first time after age 50 .

Long-term migrants potentially spend an important part of their working life in the U.S. and thus are more likely to be affected by a social security agreement between the United States and Mexico. ${ }^{6}$ The long-term migrants median length stay is four years and the average length stay is 7.8 years. Figure 1 shows the age that long-term migrants returned to Mexico after their last stay in the U.S. for those with citizenship or permanent residency or neither. We can observe a spike for U.S. citizens or residents around retirement age. This suggests some migrants return to their country of origin during retirement and life cycle decisions and possibly public retirement benefits are important. For those that are not citizens or permanent residents we observe they returned mostly during working age, the highest proportion is between 20 and 50 years old.

Figure 2 shows the year of return to Mexico for long-term migrants after their last stay in the U.S. by citizenship or residency status. Individuals with U.S. citizenship or residency are most likely to have last returned from the U.S. the year before the interview date, suggesting they move back and forth between Mexico and the U.S. more than noncitizens/residents. We can observe a different pattern for return migrants without citizenship or residency that correspond to changes in U.S. immigration programs and laws. The end of the Bracero Program in 1964 for temporary or seasonal workers may have caused the increase in the return migrants at the beginning of the 1960s. The 1986 immigration law IRCA (Immigration Reform and Control Act) may have had an effect in the decline of return migrants during the 1980s, because this law increased the immigration enforcement budget, imposed sanctions for hiring illegal immigrants, and gave amnesty to illegal immigrants. During the 1990s, we observe an increasing trend in return migrants. Implemented in 1996, the Illegal Immigration Reform and Immigrant Responsibility Act put in place more penalties for illegal entry, smuggling, further crossing deterrents such as the fencing in the border of San Diego and Tijuana, and a stronger boarder patrol using more advanced technology and more qualified agents. In addition to this reform, the Personal Responsibility, Work Opportunity, and Medicaid

\footnotetext{
${ }^{6}$ In terms of job tenure in the U.S., Aguilera (2003) found that Mexican workers have an average of 5 years using the 1992 Legalized Population Survey.
} 
Restructuring Act (PRWORA) also approved in 1996 to restrict illegal immigrants from government safety net programs and benefits. The PRWORA limited the access to welfare benefits for non-citizens, creating pressure on immigrants who were legal residents to apply for U.S. citizenship in order to fully qualify for means-tested programs (Espenshade et al, 1997; Van Hook, 2003). Although the relative importance of these programs on naturalization rates is not clear (Balistreri and Van Hook, 2004; Borjas 2002; Van Hook et al, 2006), it is clear that naturalization rates increased significantly after 1996. Regardless of the relative effects, since citizens have lower restrictions to sponsor the legal entry of their immediate relatives, higher naturalization rates increased the volume of immigration and permanent settlement as well, since families were together and there was thus less incentive to return (Massey et al, 2002).

Socio-economic Status. A very small proportion of Mexican migrants to the U.S. correspond to the lowest part of the income distribution in Mexico as indicated by indigenous language (Table 2). Only 2.7 and 2.2 percent of short-term and long-term migrants respectively, speak an indigenous language compared to 7 percent of nonmigrants. Long-term return migrants have higher economic status than short-term migrants and non-migrants, the later two having similar levels at the median.

Health. Most respondents report fair or poor current health status (Table 2). Approximately sixty percent of short-term migrants and non-migrants report fair or poor health while just over fifty percent ( 53 percent) of long-term migrants report fair or poor health. More short-term (14.6 percent) and long-term migrants (12.3 percent) indicate that they had a serious health problem before age 10 in comparisons to non-migrants ( 9.8 percent).

Health Insurance and Pensions. Table 2 shows that non-migrants have the highest coverage of health care from social security institutions (57.6 percent) although shortterm migrants have a similar rate of coverage (55.6 percent). Long-term migrants, as expected, have more private insurance than the other groups (4.1 percent) and less coverage through social security institutions (47.6 percent) or many of them do not have any type of insurance (44.2 percent). Both individuals with and without migration spells have contributed during their working life to a Mexican Social Security Institute (Table 2). Forty-four percent of short-term migrants, 38 percent of long-term migrants, and 33 percent of non-migrants have contributed to a social security institute. Due to the 
importance of Social Security benefits in retirement decisions, we return to a more detailed analysis of Social Security.

Some migrants are entitled to social security benefits in both the U.S. and Mexico. As mentioned in the institutional background, there is no agreement for portability of social security contributions between the United States and Mexico. Individuals must satisfy requirements in each system separately in order to qualify for benefits. As expected, long-term migrants are more likely to be collecting U.S. Social Security benefits than short-term migrants or non-migrants and the rates increase with age: among long-term migrants ages 65 to 69, 12 percent receive U.S. Social Security benefits (Table 3). A very small proportion of short-term migrants and non-migrants have access to U.S. social security benefits perhaps as dependent or spousal beneficiaries. Receipt of Mexican Social Security benefits is low among older Mexicans. Among non-migrants only about one-third of individuals age 60 and over are receiving benefits. The rate of benefit receipt is lower for return migrants in these age groups and lowest for the longterm migrants. For men and women there are similar levels of coverage of U.S. and Mexican social security benefits however men are more likely to have private pensions than women (results not shown).

In summary, based on Mexican respondents over age 50 in 2001, we find that 8.9 percent have lived and/or worked in the United States. Based on these results, only a small proportion of Mexicans would benefit from a Totalization Agreement although family members may too become newly entitled. In addition, the signing of an agreement would likely change who chooses to be a migrant and the migrants' behavior. We find that networks in the United States are an important factor in the decision to migrate, which is generally undertaken for the first time while individuals are between 20 and 30 years of age. There is a wide heterogeneity in terms of level of education for Mexican return migrants although the level of these cohorts is low with short-term migrants having the lowest levels of education. Long-term return migrants are the least likely of the groups to have public health insurance, which indicates low rates of current contributions to Social Security systems and thus may indicate a lower likelihood of being eligible for Social Security retirement benefits. Over half of return migrants never contributed to a Mexican social security institute. Some migrants are receiving social security benefits from the U.S.: twelve percent of long-term migrants ages 65 to 69 
receive U.S. Social Security benefits. The observed differences between migrants and non-migrants discussed here suggest that they may have different labor force behavior at older ages. We turn to an analysis of their labor supply next.

\subsection{Labor Force Status}

Labor force participation in Mexico declines with age although almost 40 percent of males are working after age 70 which may be in part due to a lack of social security and health care coverage for a substantial proportion of individuals (Table 4). We observe women of these cohorts have a low labor force participation rate. Approximately 34 percent of women 50 to 54 years old work, in comparison to 87 percent of men in the same group of age. The participation rate of women declines substantially with age and by early retirement age (age 60) is 21 per cent. Most workers have a full-time job. This may indicate preference for full-time work or a lack of flexibility of the Mexican market to provide part-time "bridge" jobs. The proportion of men in full-time work decreases with age and only a very small increase in part-time work. Among women, part-time and full-time work decrease with age.

Table 5 shows the proportion of individuals working full-time, part-time or not working according to their migration history to the United States. Return migrants are more likely to be working at all ages than non-migrants. This could indicate that individuals with truncated labor histories in the U.S. and Mexico have to work up to older ages because they do not qualify for U.S. or Mexican social security benefits. Alternatively, they may have a higher attachment to the labor force than non-migrants. Part-time work among return migrants increases from less than 10 percent to 14 percent from age 50 to 65 after which it remains fairly stable. In contrast, among non-migrants, about 10 percent engage in part-time work and this does not vary much across these same ages.

We use waves 2001 and 2003 to analyze labor transitions between working (fulltime and part-time) and not working states over 2 years by migration status in Table 6 and Table 7 and for males and females in Table 8 and 9. Transitions from work (full-time or part-time are similar for migrants and non-migrants. Non-migrants are slightly less 
likely than migrants to transition from full-time work to part-time or retirement. Return migrants are much more likely than non-migrants to 'unretire.' That is, 23 percent of return migrants are not-working in 2001 and working in 2003 while the corresponding rate for non-migrants is 14 percent. Working women are much more likely to retire between waves than men and more likely to move from full-time to part-time work (Table 8 and Table 9). Sixteen percent of full-time male workers retire between survey waves and 33 percent of full-time women. Women are also less likely to 'unretire' between waves compared with men.

In sum, we find that about a third of individuals are still working at normal retirement age. Women have much lower labor force participation than men and transition to retirement earlier. We observe small proportion of persons in part-time jobs but it seems to slightly increase towards retirement age for men and individuals with migration spells to the United States. Also, a higher proportion of individuals with migration spells to the U.S. are working around retirement age and at older ages in comparison to those with no migration spells to the U.S. We find similar patterns of labor transitions from full-time to part-time work and retirement for individuals with and without migration spells. Slightly more individuals with migration spells are re-entering the labor market after retirement. In the next section we analyze the main determinants for retirement for individuals with and without migration spells.

\subsection{Determinants of Transitions to Retirement}

Retirement decisions depend on health status, accumulation of wealth, social security entitlements, among other factors. In this section we analyze the factors that affect retirement decisions for Mexicans with and without migration spells to the United States. We model the probability of retiring in 2003, conditional on working in 2001 using a probit model. Table 10 shows the results for males with migration spells to the U.S., and males and females without migration spells to the United States. ${ }^{7}$

Factors that increase the probability of retirement for male return migrants are poor health, public health insurance, public Social Security, particularly being newly age eligible for benefits and household income. Public health insurance increases retirement by 0.089 . Having ever contributed to a Mexican Social Security system and being newly age eligible for benefits (age 60 or 61 in 2003) increases the probability of retiring

\footnotetext{
${ }^{7}$ There are too few female migrants for multivariate estimation.
} 
substantially, by 0.29 compared to return migrants without contributions to a public Social Security. Receiving U.S. social security benefits increases the probability of retiring by another 0.27 relative to not having these benefits although due to large standard errors, the effect is not statistically different than zero. These estimates reveal the importance of public pension benefits in the decision to retire for return migrants. Access to U.S. Social Security may be interpreted as a wealth effect. In addition, receipt of this benefit may induce Mexican migrants in the U.S. to return to Mexico. Interestingly, there is no additional effect of net household wealth. Relative to having very good or excellent health, poor health increases the probability of retirement by 0.22 .

In the third column we show the results for males without migration spells to the United States. Only a few of the factors associated with increases in the probability of retirement are the same for non-migrant males as for return migrant males and the size of the effect differs. Public health insurance, and public Social Security, particularly being age eligible for benefits all increase the probability of retirement however the effects are much smaller for non-migrants compared to migrants $(0.04$ and 0.07 respectively for health insurance and newly age eligible for public social security). In contrast to migrants, poor health does not increase the likelihood of retirement, high education decreases the likelihood of retirement and there is no effect of household income.

The determinants of retirement for non-migrant females are much different than those for non-migrants (and migrant) males with the exception that contribution to a Social Security system and being newly age eligible for benefits increases retirement relative to those without a public pension program $(0.16)$ and the size of the effect is substantial (baseline retirement hazard is 0.35). Higher education is associated with a decrease in the propensity to retire. For example, a high school graduate decreases the probability of retiring by 0.15 . While number of children had no effect on male retirement, for females, children are associated with a substantial increase in the probability of retiring. This might be explained by the importance of transfers from children to older parents, particularly to the mother. Public health insurance has no effect on retirement relative to having no health insurance. Health has a large effect, increasing the probability of retirement with good, fair and poor health all increasing the probability of retirement by about 0.20 relative to excellent health. 
The findings in Table 10 are generally consistent with the previous literature on retirement behavior in the U.S. and many other developed countries, highlighting the importance of social security systems and health status. While the retirement behavior of return migrant males is much more responsive to public benefit compared to that of nonmigrant males, and the importance of receiving U.S. social security benefits in inducing retirement among return migrant males is worthy of additional research. In addition, the impact of children on the retirement behavior of women suggests family transfers as a resource in retirement may be a particularly important factor for women.

\section{Conclusions}

This study examined the characteristics and retirement behavior of Mexicans with and without migration spells to the United States. The data set used, MHAS, provides a nationally representative sample of Mexicans 50 years and older. These data provide a broader perspective of migration histories than other surveys because the respondents have completed most of their working lives. Most of the return migrants first went to the U.S. in their twenties and thirties and among those that returned, migrants with U.S. citizenship or residency status had a propensity to do so near retirement age.

The birth cohorts represented in the MHAS have very low levels of schooling with short-term return migrants having the lowest levels. Many Mexicans do not have access to public health insurance and will not benefit from public retirement pension. Around $40 \%$ of individuals do not have health care insurance and $50 \%$ have never contributed to a Mexican social security institute. Long-term return migrants are the least likely to have public health insurance, which indicates low rates of current contributions to Social Security systems and thus may indicate a lower likelihood of being eligible for Social Security retirement benefits. Over half of return migrants never contributed to a Mexican social security institute. This is consistent with truncated labor histories in the U.S. and Mexico but may also reflect the selection of who chooses to be a long-term migrant. However, 12 percent of long-term migrants age 65 to 69 are receiving U.S. Social Security benefits.

Work for males over age 70 is common and more likely for return migrants than non-migrants. Part-time work increases slightly close to normal retirement age. Labor transition patterns of return migrants and non-migrants are similar but migrants re-enter 
the labor market in a higher proportion after retirement. Middle-aged and elderly female labor force participation is quite low in comparison to men.

The finding that public programs are important factors in the retirement decision is consistent with the previous literature on retirement behavior. Only a few of the factors associated with increases in the probability of retirement are the same for non-migrant males as for return migrant males. Public health insurance, and public Social Security, particularly being age eligible for benefits all increase the probability of retirement however the effects are much smaller for non-migrants compared to migrants. While poor health appears to push return migrants out of the labor force, it has no effect on nonmigrant males. Although female non-migrants also respond to being newly age eligible for Social Security benefits, many of the determinants of retirement for non-migrant females are much different than those for non-migrants (and migrant) males with household characteristics such as marital status and number of children playing an important role.

According to the $2001 \mathrm{MHAS}$, the proportion of Mexicans 50 years and older who report having worked or lived in the United States is just under 10 percent. The responsiveness of current older Mexican workers to pension benefits, suggests that an Agreement would certainly affect the retirement behavior of Mexican migrants. The proposed agreement would likely increase the number of authorized and unauthorized Mexican workers and family member eligible for Social Security benefits and change migration behavior in terms of who migrates to the United States from Mexico, how long they stay and whether they return. 
References

Agreement on Social Security between the Unites States of America and the United Mexican States, 2004.

Aguila, Emma, "Personal Retirement Accounts and Saving," RAND Working Paperwr$600,2008$.

_ College London, 2006.

Aguilera, M. B., "The Impact of the Worker: How Social Capital and Human Capital Influence the Job Tenure of Formerly Undocumented Mexican Immigrants," Sociological Inquiry, Vol. 73, No. 1, 2003, pp. 52-83.

Angel, J. L., "Devolution and the Social Welfare of Elderly Immigrants: Who Will Bear the Burden?," Public Administration Review, Vol. 63, No. 1, 2003, pp. 79-89.

Balistreri, Kelly S. and Jennifer Van Hook, "The more things change the more they stay the same: Mexican naturalization before and after welfare reform," International Migration Review, Vol. 38, No. 1, 2004, pp. 113-130.

Borjas, George. "Welfare reform and immigration." In The New World of Welfare, Blank, R. and R. Haskins, ed. Washington, D.C.: Brookings Institution Press, 2002.

Butcher, Paul and Joseph Erdos, "International Social Security Agreements: The U.S. Experience," Social Security Bulletin, Vol. 51, No. 9, September 1988, p. 4.

Duncan, B., Hotz, V., and Trejo, S. J., "Hispanics in the U.S. Labor Market," California Center for Population Research University of California Los Angeles On-Line Working Paper Series CCPR-040-05., 2005.

Espenshade, Thomas J, Jessica L. Baraka, and Gregory A. Huber, "Implications of the 1996 Welfare and Immigration Reform Acts for US Immigration," Population and Development Review, Vol. 23, No. 4, 1997, pp. 769-801.

Flippen, C., "Pathways to retirement: patterns of labor force participation and labor market exit among the pre-retirement population by race, Hispanic origin, and sex," Journals of Gerontology Series B: Psychological Sciences and Social Sciences, Vol. 55, No. 1, 2000, pp. 14-27.

Fry, R., \& Lowell, B. L., "The Wage Structure of Latino-Origin Groups across Generations," Industrial Relations: A Journal of Economy and Society, Vol. 45, No. 2, 2006, pp. 147-168.

Greenlees, C. and R. Sáenz, "Determinants of Employment of Recently Arrived Mexican Immigrant Wives," International Migration Review, Vol. 33, No. 2, 1999, pp. 354-377.

Gruber, J., Wise, D. A., ed. Social Security Programs and Retirement around the World: Micro-Estimation: NBER, The University of Chicago Press, 2004. 
Hurd, Michael D., "Research on the Elderly: Economic Status, Retirement, and Consumption and Savings," Journal of Economic Literature, Vol. 28, 1990, pp. 565-637.

Lumsdaine, R., Mitchell, O. "New Developments in the Economics of Retirement Handbook of Labor Economics." In Handbook of Labor Economics, Ashenfelter, O., Card, D., ed. North Holland, Amsterdam, 3261.3308, 1999.

Martínez "Convenio de Seguridad Social entre Estados Unidos de América y México," Cartagena, Augost 2007.

Massey, Douglas. S., Jorge Durand, and Noland J. Malone, Beyond Smoke and Mirrors: Mexican Immigration in an era of Economic Integration New York: Russell Sage Foundation, 2002.

Migration Between Mexico \& the United States, "Binational Study on Migration," 1997.

Miranda-Munoz, "Pensions and Retirement from the Labor Market: Contrasts Among Countries," Seguridad Social Journal, Vol. 251, No. 14, 2004.

Organización Panamericana de la Salud (OPS), "Perfil del sistema de servicios de salud. México," April 2002, http://www.lachealthsys.org/index.php?option=com_docman\&task=doc_downloa $\mathrm{d} \& \mathrm{gid}=138$ (as of September 15, 2007).

Orrenius, Pia, "The Role of Family Networks, Coyote Prices and the Rural Economy in Migration from Western Mexico: 1965-1994," Federal Reserve Bank of Dallas, WP9910, 1999.

Palloni, A., Arias, E., "Paradox Lost: Explaining The Hispanic Adult Mortality Advantage," Demography, Vol. 41, No. 3, 2004, pp. 385-415.

Perfil del sistema de servicios de salud, April 2002, http://www.lachealthsys.org/index.php?option=com_docman\&task=doc_downloa $\mathrm{d} \& \mathrm{gid}=138$.

Rust, J. and C. Phelan, "How Social Security and Medicare affect retirement behaviour in a world of incomplete markets," Econometrica, Vol. 65, No. 4, 1997, pp. 781831.

Soldo, B.J., Wong, R., and Palloni, A., "Migrant Health Selection: Evidence from Mexico and the US," Population Association of America Conference, Atlanta, May 2002.

Toussaint-Comeau, M., "The Occupational Assimilation of Hispanic Immigrants in the US: Evidence from Panel Data 1," International Migration Review, Vol. 40, No. 3, 2006, pp. 508-536.

UNDP, "Informe Sobre el Desarrollo Humano México 2006-2007: Migración y Desarrollo Humano," 2007.

Van Hook, Jennifer, "Welfare reform's chilling effects on noncitizens: changes in noncitizen welfare recipiency or shifts in citizenship status?," Social Science Quarterly, Vol. 84, No. 3, 2003, pp. 613-631. 
Van Hook, Jennifer, Susan K. Brown, and Frank D. Bean, "For love or for money? Welfare reform and immigrant naturalization," Social Forces, Vol. 85, No. 2 , 2006, pp. 643-666.

Warner, D.C. and Jahnke, L., "Toward better access to health insurance coverage for U.S. retirees in Mexico," Salúd Pública de México, Vol. 43, No. 1, January/February 2001, pp. 59-66.

Warner, David C. , Getting What You Paid For: Extending Medicare to Eligible Beneficiaries in Mexico: LBJ School of Public Affairs, University of Texas, Austin, 1999.

Wong, R., Espinoza, M., "Imputation of Non-Response on Economic Variables in theMexican Health and Aging Study (MHAS/ENASEM) 2001: Project Report," 2004, http://www.mhas.pop.upenn.edu/.

Wong, R., Espinoza, M.,, "Ingreso y Bienes de la Población en Edad Media y Avanzada en México [Income and Assets of the Middle and Old Age in Mexico]," Papeles de Población, Centro de Investigación y Estudios Avanzados de la Población UAEM, 37, 2003.

Wong, R. Soldo, B.J., and Palloni, A. "Wealth in Middle- and Old- Age: The Role if International Migration in Mexico," In Population Association of America Conference, Minneapolis, May 2003. 
Table 1: Characteristics of the Sample

(\%)

\begin{tabular}{|c|c|}
\hline & MHAS \\
\hline Number of observations & 13,550 \\
\hline Mean age & 62.6 \\
\hline \multicolumn{2}{|l|}{ Groups of age } \\
\hline 50-54 years old & 24.3 \\
\hline 55-59 years old & 21.4 \\
\hline $60-64$ years old & 17.2 \\
\hline 65-69 years old & 13.8 \\
\hline $70-74$ years old & 10.0 \\
\hline 75-79 years old & 6.8 \\
\hline 80 years old or more & 6.5 \\
\hline Male & 46.1 \\
\hline Female & 53.9 \\
\hline \multicolumn{2}{|l|}{ Education } \\
\hline No schooling & 25.3 \\
\hline Incomplete primary & 35.0 \\
\hline Primary & 17.8 \\
\hline Incomplete high school & 4.7 \\
\hline High School & 9.5 \\
\hline Undergraduate or more & 7.3 \\
\hline \multicolumn{2}{|l|}{ Number of children } \\
\hline None & 5.2 \\
\hline 1 or 2 & 11.5 \\
\hline 3 to 5 & 32.2 \\
\hline 6 to 8 & 26.1 \\
\hline More than 9 & 24.5 \\
\hline \multicolumn{2}{|l|}{ Marital Status } \\
\hline Single & 3.8 \\
\hline Married & 60.7 \\
\hline Consensual union & 5.5 \\
\hline Divorced & 1.5 \\
\hline Separated & 6.7 \\
\hline Widowed & 18.5 \\
\hline \multicolumn{2}{|l|}{ Live in locality size: } \\
\hline More 100,000 inhabitants & 58.8 \\
\hline $15,000-99,999$ inhabitants & 14.8 \\
\hline $2,500-14,999$ inhabitants & 9.2 \\
\hline Less 2,500 inhabitants & 17.2 \\
\hline Migration histories to the U.S. & 8.9 \\
\hline Speak indigenous language & 6.8 \\
\hline
\end{tabular}


Table 2: Characteristics of Individuals By Migration Status

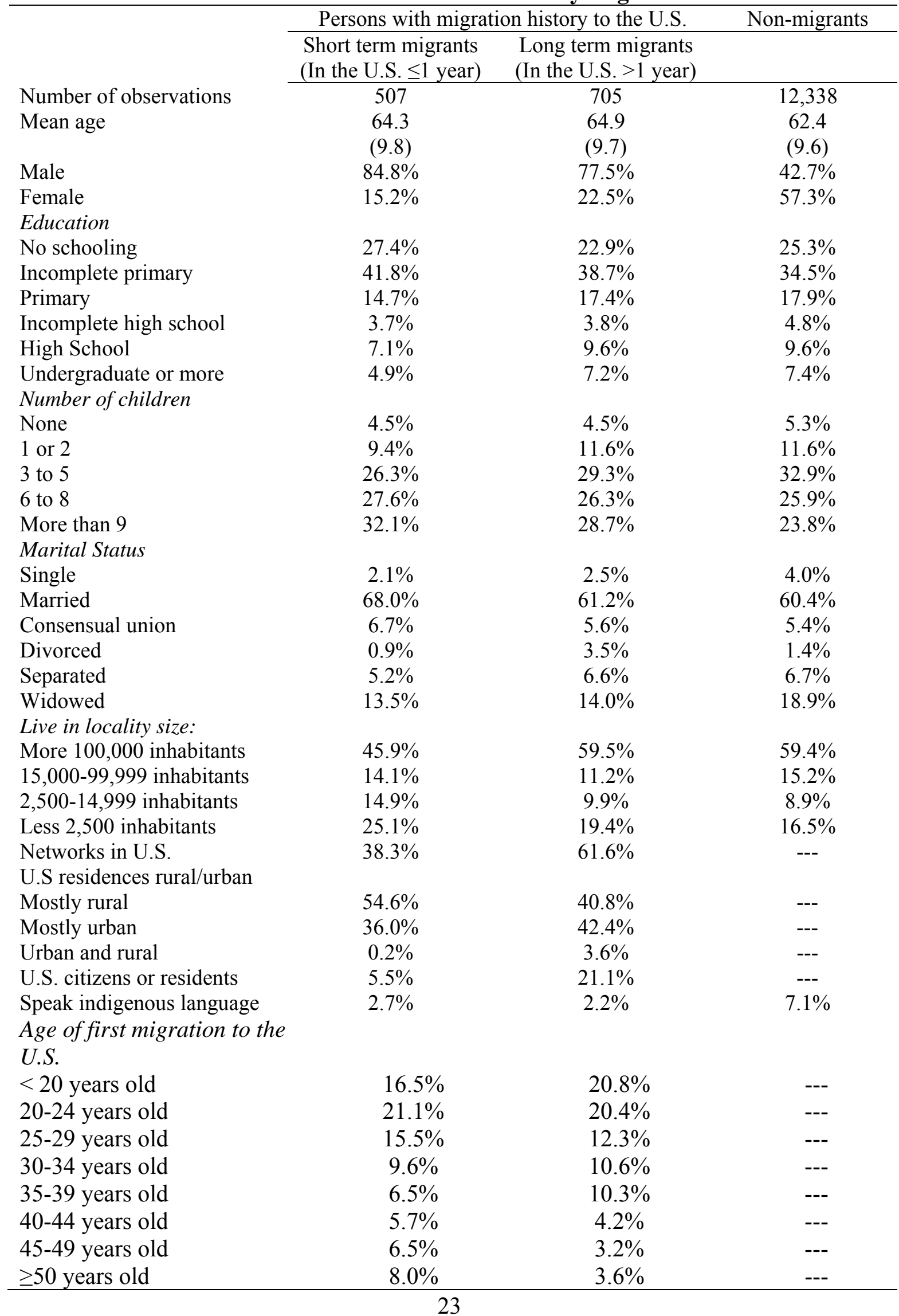




\section{Cont. Table 2: Characteristics of individuals with and without migration to the}

United State.

\begin{tabular}{|c|c|c|c|}
\hline & \multicolumn{2}{|c|}{ Persons with migration history to the U.S. } & \multirow[t]{2}{*}{ Non-migrants } \\
\hline & $\begin{array}{l}\text { Short term migrants } \\
\text { (staying in the U.S. } \\
\leq 1 \text { year) }\end{array}$ & $\begin{array}{l}\text { Long term migrants } \\
\text { (staying in the U.S. } \\
>1 \text { year) }\end{array}$ & \\
\hline Mean household income(US\$) & $\begin{array}{cc}\$ 56.4 \\
(417.1)\end{array}$ & $\begin{array}{c}\$ 188.2 \\
(2711.2)\end{array}$ & $\begin{array}{c}\$ 81.2 \\
(854.8)\end{array}$ \\
\hline $\begin{array}{l}\text { Median monthly household } \\
\text { income (US\$) }\end{array}$ & $\$ 23.8$ & $\$ 30.3$ & $\$ 22.8$ \\
\hline $\begin{array}{l}\text { Mean household net worth } \\
\text { (US\$) }\end{array}$ & $\begin{array}{l}\$ 3,540.5 \\
(7047.6)\end{array}$ & $\begin{array}{l}\$ 4,064.0 \\
(7497.8)\end{array}$ & $\begin{array}{l}\$ 3,684.0 \\
(7367.8)\end{array}$ \\
\hline $\begin{array}{l}\text { Median household net worth } \\
\text { Self-reported health status }\end{array}$ & $\$ 1,937.0$ & $\$ 2,264.9$ & $\$ 1,938.7$ \\
\hline Excellent & $2.5 \%$ & $2.9 \%$ & $1.6 \%$ \\
\hline Good & $3.7 \%$ & $6.1 \%$ & $3.8 \%$ \\
\hline Very good & $25.4 \%$ & $27.2 \%$ & $28.9 \%$ \\
\hline Fair & $39.4 \%$ & $37.1 \%$ & $43.9 \%$ \\
\hline Poor & $22.2 \%$ & $15.8 \%$ & $14.6 \%$ \\
\hline Childhood health indicator & & & \\
\hline $\begin{array}{l}\text { Serious health problem before } \\
\text { age } 10 \\
\text { Health Insurance }\end{array}$ & $14.6 \%$ & $12.3 \%$ & $9.8 \%$ \\
\hline Public insurance & $55.6 \%$ & $47.6 \%$ & $57.6 \%$ \\
\hline Private insurance & $1.1 \%$ & $4.1 \%$ & $1.9 \%$ \\
\hline None & $42.2 \%$ & $44.2 \%$ & $37.9 \%$ \\
\hline $\begin{array}{l}\text { Ever contributed to a Mexican } \\
\text { Social Security Institute } \\
\text { Males }\end{array}$ & & & \\
\hline IMSS & $39.0 \%$ & $36.2 \%$ & $44.2 \%$ \\
\hline ISSSTE & $6.7 \%$ & $3.3 \%$ & $7.0 \%$ \\
\hline Other & $0.7 \%$ & $1.1 \%$ & $1.6 \%$ \\
\hline None & $50.6 \%$ & $57.0 \%$ & $44.7 \%$ \\
\hline Females & & & \\
\hline IMSS & $24.6 \%$ & $21.3 \%$ & $14.3 \%$ \\
\hline ISSSTE & $2.6 \%$ & $3.7 \%$ & $3.7 \%$ \\
\hline Other & $1.3 \%$ & $2.5 \%$ & $0.3 \%$ \\
\hline None & $70.1 \%$ & $69.8 \%$ & $78.3 \%$ \\
\hline
\end{tabular}

NOTE: The amounts are in US dollars; the exchange rate is $\$ 10.00$ pesos per dollar. The health insurance variable includes a category for other type of insurance apart from private or public. This category is not included in the table. Categories do not add up to $100 \%$ because they include missing observations. In the category Ever contributed to a Mexican Social Security Institute, None includes individuals that have never worked. In the case of females the proportion that has never worked is quite high, $16.8 \%$ for short-term migrants, $19.5 \%$ for long-term migrants, and $32.8 \%$ for non-migrants.

SOURCE: Authors calculation using 2001 the Mexican Health and Aging Study (MHAS). 
Table 3: Receipt of Social Security Benefits by Age and Migration Status

\begin{tabular}{lccc}
\hline & $\begin{array}{c}\text { U.S. Social } \\
\text { Security }\end{array}$ & $\begin{array}{c}\text { Mexican Social } \\
\text { Security }\end{array}$ & Private Pensions \\
\hline Short Term Migration & & & \\
$50-54(\mathrm{~N}=95)$ & $1.0 \%$ & $5.2 \%$ & $0.0 \%$ \\
$55-59(\mathrm{~N}=97)$ & $0.0 \%$ & $11.3 \%$ & $2.0 \%$ \\
$60-65(\mathrm{~N}=85)$ & $0.0 \%$ & $21.1 \%$ & $0.0 \%$ \\
$65-69(\mathrm{~N}=87)$ & $1.1 \%$ & $26.4 \%$ & $3.4 \%$ \\
70 or more $(\mathrm{N}=143)$ & $0.7 \%$ & $32.1 \%$ & $2.1 \%$ \\
& & & \\
Long Term Migration & & & \\
$50-54(\mathrm{~N}=124)$ & $0.8 \%$ & $8.8 \%$ & $0.0 \%$ \\
$55-59(\mathrm{~N}=119)$ & $1.6 \%$ & $9.2 \%$ & $0.0 \%$ \\
$60-65(\mathrm{~N}=115)$ & $12.9 \%$ & $18.2 \%$ & $0.8 \%$ \\
$65-69(\mathrm{~N}=125)$ & $8.0 \%$ & $24.0 \%$ & $2.7 \%$ \\
70 or more $(\mathrm{N}=222)$ & & $20.7 \%$ & \\
& & & \\
No Migration spells & $0.0 \%$ & $9.6 \%$ & $1.0 \%$ \\
$50-54(\mathrm{~N}=3,062)$ & $0.2 \%$ & $17.1 \%$ & $1.2 \%$ \\
$55-59(\mathrm{~N}=2,690)$ & $0.2 \%$ & $27.8 \%$ & $1.5 \%$ \\
$60-65(\mathrm{~N}=2,110)$ & $0.3 \%$ & $31.0 \%$ & $1.9 \%$ \\
$65-69(\mathrm{~N}=1,661)$ & $0.2 \%$ & $29.8 \%$ & $1.5 \%$ \\
70 or more $(\mathrm{N}=2,815)$ & & &
\end{tabular}

SOURCE: Author's calculation using the 2001 Mexican Health and Aging Study (MHAS). 
Table 4: Labor status by groups of age and gender

\begin{tabular}{|c|c|c|c|}
\hline & Full-time work & Part-time work & Not working \\
\hline \multicolumn{4}{|l|}{ Males } \\
\hline $50-54(\mathrm{~N}=1,485)$ & $77.7 \%$ & $9.23 \%$ & $11.3 \%$ \\
\hline $55-59(\mathrm{~N}=1,353)$ & $68.3 \%$ & $12.5 \%$ & $17.4 \%$ \\
\hline $60-65(\mathrm{~N}=1,031)$ & $55.0 \%$ & $13.6 \%$ & $29.9 \%$ \\
\hline $65-69(\mathrm{~N}=882)$ & $43.0 \%$ & $13.7 \%$ & $41.7 \%$ \\
\hline 70 or more $(\mathrm{N}=1,499)$ & $24.7 \%$ & $13.4 \%$ & $60.5 \%$ \\
\hline \multicolumn{4}{|l|}{ Females } \\
\hline $50-54(\mathrm{~N}=1,796)$ & $22.6 \%$ & $10.5 \%$ & $66.0 \%$ \\
\hline $55-59(\mathrm{~N}=1,553)$ & $18.8 \%$ & $9.4 \%$ & $71.0 \%$ \\
\hline $60-65(\mathrm{~N}=1,279)$ & $12.3 \%$ & $8.7 \%$ & $78.1 \%$ \\
\hline $65-69(\mathrm{~N}=991)$ & $7.3 \%$ & $6.5 \%$ & $84.8 \%$ \\
\hline 70 or more $(\mathrm{N}=1,681)$ & $4.3 \%$ & $4.1 \%$ & $90.7 \%$ \\
\hline \multicolumn{4}{|c|}{$\begin{array}{l}\text { NOTE: Categories do not add up to } 100 \% \text { because they include missing observations. Not working } \\
\text { includes individuals that have never worked. Those that have never worked represent an important } \\
\text { proportion for females. } 26.7 \% \text { for the groups } 50 \text { to } 54 \text { years old, } 30.3 \% \text { for } 55-59,32.6 \% \text { for } 60-65,34.2 \% \\
\text { for } 65-69 \text {, and } 38.9 \% \text { for } 70 \text { years old or more. } \\
\text { SOURCE: Author's calculation using the } 2001 \text { Mexican Health and Aging Study (MHAS). }\end{array}$} \\
\hline
\end{tabular}

Table 5: Labor status for individuals with and without migration spells to the U.S. $(\%)$

Full-time work $\quad$ Part-time work Not working

With Migration spells

\begin{tabular}{lccc}
$50-54(\mathrm{~N}=219)$ & $61.1 \%$ & $10.5 \%$ & $27.3 \%$ \\
$55-59(\mathrm{~N}=216)$ & $62.0 \%$ & $12.9 \%$ & $24.4 \%$ \\
$60-65(\mathrm{~N}=200)$ & $51.5 \%$ & $14.0 \%$ & $34.0 \%$ \\
$65-69(\mathrm{~N}=212)$ & $38.6 \%$ & $15.5 \%$ & $43.3 \%$ \\
70 or more $(\mathrm{N}=365)$ & $23.5 \%$ & $15.0 \%$ & $60.7 \%$ \\
& & & \\
With no Migration spells & & & $42.2 \%$ \\
$50-54(\mathrm{~N}=3,062)$ & $46.6 \%$ & $9.9 \%$ & $47.9 \%$ \\
$55-59(\mathrm{~N}=2,690)$ & $40.2 \%$ & $10.7 \%$ & $58.8 \%$ \\
$60-65(\mathrm{~N}=2,110)$ & $29.5 \%$ & $10.6 \%$ & $67.3 \%$ \\
$65-69(\mathrm{~N}=1,661)$ & $22.3 \%$ & $9.2 \%$ & $78.4 \%$ \\
70 or more $(\mathrm{N}=2,815)$ & $12.7 \%$ & $7.6 \%$ & \\
\hline 07
\end{tabular}

NOTE: Categories do not add up to $100 \%$ because they include missing observations. Not working includes individuals that have never worked. Those that have never worked represent an important proportion for individuals with no migration spells. $15.4 \%$ for the groups 50 to 54 years old, $17.5 \%$ for 55 $59,20.0 \%$ for $60-65,20.4 \%$ for $65-69$, and $22.9 \%$ for 70 years old or more.

SOURCE: Author's calculation using the 2001 Mexican Health and Aging Study (MHAS). 
Table 6: Labor market transitions for return migrants

\begin{tabular}{|c|c|c|c|}
\hline$t-1$ & Full-time work & Part-time work & Retirement \\
\hline Full-time work ( $\mathrm{N}=474$ ) & $65.8 \%$ & $12.9 \%$ & $21.3 \%$ \\
\hline Part-time work $(\mathrm{N}=153)$ & $35.3 \%$ & $31.4 \%$ & $33.3 \%$ \\
\hline Retirement $(\mathrm{N}=375)$ & $13.3 \%$ & $8.3 \%$ & $78.4 \%$ \\
\hline
\end{tabular}

SOURCE: Author's calculation using the 2001 and 2003 Mexican Health and Aging Study (MHAS).

Table 7: Labor market transitions for non-migrants

\begin{tabular}{|c|c|c|c|}
\hline $\mathrm{t}-1$ & Full-time work & Part-time work & Retirement \\
\hline Full-time work $(\mathrm{N}=3,430)$ & $70.1 \%$ & $10.3 \%$ & $19.6 \%$ \\
\hline Part-time work $(\mathrm{N}=1,063)$ & $32.3 \%$ & $28.9 \%$ & $38.8 \%$ \\
\hline Retirement $(\mathrm{N}=4,221)$ & $8.2 \%$ & $5.9 \%$ & $85.9 \%$ \\
\hline
\end{tabular}

SOURCE: Author's calculation using the 2001and 2003 Mexican Health and Aging Study (MHAS).

Table 8: Labor market transitions for males

\begin{tabular}{lccc}
\hline $\mathrm{t}-1$ & Full-time work & Part-time work & Retirement \\
\hline Full-time work $(\mathrm{N}=3,006)$ & $74.5 \%$ & $9.6 \%$ & $15.9 \%$ \\
Part-time work $(\mathrm{N}=692)$ & $39.7 \%$ & $30.2 \%$ & $30.1 \%$ \\
Retirement $(\mathrm{N}=1,641)$ & $16.5 \%$ & $8.5 \%$ & $75.0 \%$ \\
\hline
\end{tabular}

SOURCE: Author's calculation using the 2001 and 2003 Mexican Health and Aging Study (MHAS).

Table 9: Labor market transitions for females

\begin{tabular}{|c|c|c|c|}
\hline $\mathrm{t}-1$ & Full-time work & Part-time work & Retirement \\
\hline Full-time work $(\mathrm{N}=898)$ & $53.1 \%$ & $13.9 \%$ & $33.0 \%$ \\
\hline Part-time work ( $\mathrm{N}=524)$ & $23.5 \%$ & $27.9 \%$ & $48.6 \%$ \\
\hline Retirement $(\mathrm{N}=2,955)$ & $4.2 \%$ & $4.8 \%$ & $91.0 \%$ \\
\hline
\end{tabular}

SOURCE: Author's calculation using the 2001 and 2003 Mexican Health and Aging Study (MHAS). 
Table 10: Probability of retirement for individuals with and without migration spells

\begin{tabular}{|c|c|c|c|c|c|c|}
\hline & \multicolumn{2}{|c|}{ Migrant male } & \multicolumn{2}{|c|}{ Non-Migrant male } & \multicolumn{2}{|c|}{ Non-migrant female } \\
\hline & Coeff. & S.E. & Coeff. & S.E. & Coeff. & S.E. \\
\hline Age & 0.012 & 0.025 & 0.020 & $0.010 * *$ & 0.006 & 0.026 \\
\hline $\mathrm{Age}^{\wedge} 2$ & -0.000 & 0.000 & -0.000 & 0.000 & -0.000 & 0.000 \\
\hline \multicolumn{7}{|l|}{ Education } \\
\hline Incomplete primary & 0.043 & 0.037 & 0.010 & 0.017 & 0.011 & 0.037 \\
\hline Primary & -0.054 & 0.039 & 0.007 & 0.021 & -0.058 & 0.042 \\
\hline High School & 0.043 & 0.066 & -0.008 & 0.023 & -0.149 & $0.044 * * *$ \\
\hline Undergraduate or more & -0.005 & 0.084 & -0.067 & $0.020 * * *$ & -0.098 & 0.058 \\
\hline \multicolumn{7}{|l|}{ Number of children } \\
\hline 1 or 2 children & 0.132 & 0.159 & -0.022 & 0.030 & 0.057 & 0.065 \\
\hline 3 to 5 children & 0.119 & 0.128 & -0.020 & 0.029 & 0.084 & 0.059 \\
\hline 6 to 8 children & 0.113 & 0.126 & -0.041 & 0.027 & 0.153 & $0.063 * *$ \\
\hline More than 9 children & 0.065 & 0.110 & -0.034 & 0.027 & 0.197 & $0.067 * * *$ \\
\hline Married & 0.019 & 0.033 & 0.023 & 0.014 & 0.077 & $0.029 * * *$ \\
\hline Speak indigenous language & 0.002 & 0.079 & 0.004 & 0.022 & 0.092 & 0.058 \\
\hline \multicolumn{7}{|l|}{ Health insurance } \\
\hline Public health & 0.089 & $0.036 * *$ & 0.036 & $0.015^{* *}$ & 0.003 & 0.032 \\
\hline Private health & $\mathrm{N} / \mathrm{A}$ & & -0.017 & 0.044 & -0.066 & 0.086 \\
\hline \multicolumn{7}{|l|}{ Health status } \\
\hline Very good health status & -0.114 & 0.029 & 0.039 & 0.058 & 0.206 & 0.141 \\
\hline Good health status & 0.000 & 0.070 & 0.022 & 0.045 & 0.215 & $0.115^{*}$ \\
\hline Fair health status & 0.039 & 0.073 & 0.061 & 0.047 & 0.197 & $0.108^{*}$ \\
\hline Poor health status & 0.218 & $0.127 * *$ & 0.068 & 0.061 & 0.218 & $0.124^{*}$ \\
\hline Childhood health problems & 0.026 & 0.043 & -0.006 & 0.020 & 0.162 & 0.043 \\
\hline \multicolumn{7}{|l|}{ Mexican Social Security } \\
\hline not age eligible & 0.019 & 0.065 & 0.040 & $0.023 *$ & -0.034 & 0.041 \\
\hline Newly age eligible in 2003 & 0.290 & $0.116 * * *$ & 0.072 & $0.035 * *$ & 0.161 & $0.082 * *$ \\
\hline Already eligible & 0.019 & 0.042 & 0.066 & $0.022 * * *$ & 0.098 & $0.061 *$ \\
\hline \multicolumn{7}{|l|}{ Income and wealth quintiles } \\
\hline Household income quintiles 2 & 0.164 & $0.065 * * *$ & -0.033 & $0.017 *$ & 0.015 & 0.043 \\
\hline Household income quintiles 3 & 0.123 & $0.066 * *$ & -0.027 & 0.018 & -0.067 & 0.041 \\
\hline Household income quintiles 4 & 0.110 & $0.069 *$ & 0.012 & 0.020 & -0.064 & 0.043 \\
\hline Household income quintiles 5 & 0.114 & $0.064 * *$ & 0.029 & 0.023 & -0.036 & 0.048 \\
\hline Household net worth quintiles 2 & 0.078 & 0.056 & -0.014 & 0.018 & -0.006 & 0.042 \\
\hline Household net worth quintiles 3 & 0.003 & 0.045 & 0.007 & 0.019 & -0.059 & 0.042 \\
\hline Household net worth quintiles 4 & 0.079 & 0.057 & -0.000 & 0.019 & 0.060 & 0.044 \\
\hline Household net worth quintiles 5 & 0.023 & 0.054 & -0.011 & 0.020 & 0.021 & 0.045 \\
\hline U.S. social security benefits & 0.271 & 0.235 & & & & \\
\hline \multicolumn{7}{|l|}{ Age of first migration } \\
\hline$<20$ years old & -0.020 & 0.055 & & & & \\
\hline $20-29$ years old & -0.086 & $0.049^{*}$ & & & & \\
\hline $30-39$ years old & -0.080 & 0.042 & & & & \\
\hline 40-49 years old & -0.010 & 0.068 & & & & \\
\hline 50 years old or more & $\mathrm{N} / \mathrm{A}$ & & & & & \\
\hline
\end{tabular}




\section{Cont. Table 10: Probability of retirement for individuals with and without}

\begin{tabular}{lcclll}
\hline & \multicolumn{2}{c}{ Migrant male } & \multicolumn{2}{l}{ Non-Migrant male } & \multicolumn{2}{c}{ Non-Migrant female } \\
\cline { 2 - 5 } & Coeff. & S.E. & Coeff. & S.E. & Coeff. \\
\cline { 2 - 5 } U.S. citizen/resident & -0.030 & 0.043 & & & \\
Long-term migrant & 0.033 & 0.029 & & & \\
Number of observations & 546 & & 3,123 & 1,359 \\
Observed probability & 0.195 & & 0.152 & 0.345 \\
Pseudo R`2 & 0.243 & & 0.107 & 0.075 \\
\hline
\end{tabular}

migration spells

NOTE: The model is not estimated to migrant females due to the small sample size. N/A is that the coefficient is not available because the sample size in this cell is too small (36 observations for private health insurance of migrants and 3 observations for ever contributed to other Mexican social security institute). The benchmark categories are: no schooling, no children, single, excellent health status, no public or private heath care insurance, never contributed to a public pension system, $20^{\text {th }}$ percentile of household income and household net worth and age of first migration to the US at 50 years old or more. ${ }^{*} \mathrm{p}<0.1, * * \mathrm{p}<.05, * * * \mathrm{p}<0.01$.

SOURCE: Author's calculation using the 2001 and 2003 Mexican Health and Aging Study (MHAS) 
Figure 1: Age of return to Mexico for long-term migrants

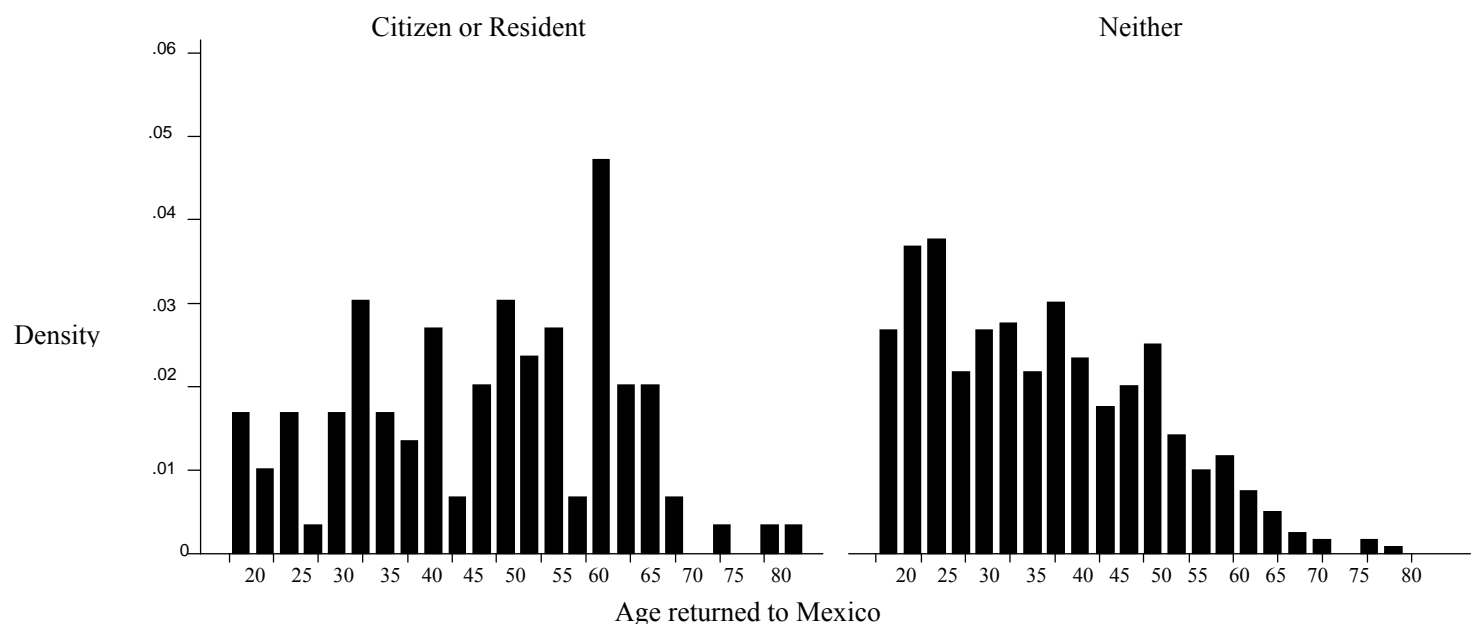

SOURCE: Author's calculation using the 2001 Mexican Health and Aging Study (MHAS).

Figure 2: Year of return to Mexico for long-term migrants

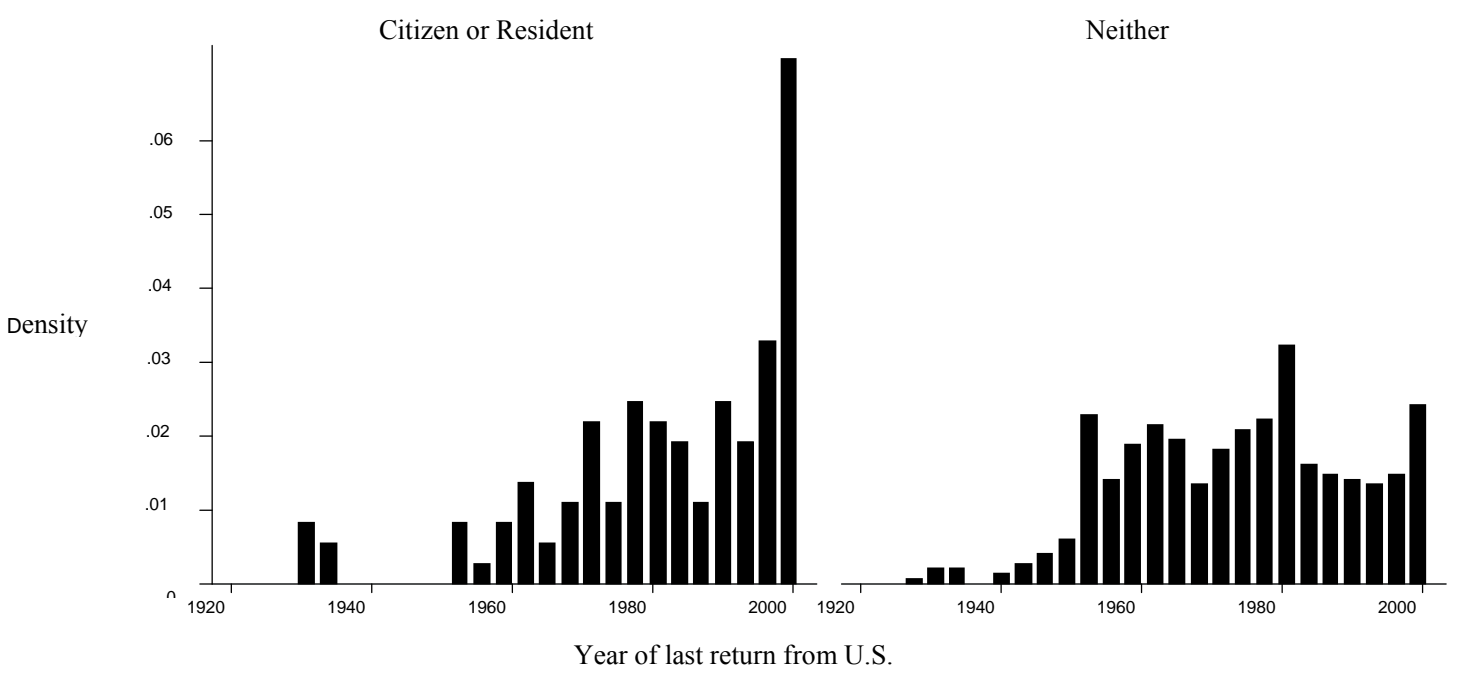

SOURCE: Author's calculation using the 2001 Mexican Health and Aging Study (MHAS). 